\title{
Gisèle Mathieu-Castellani, Eros baroque. Anthologie thématique de la poésie amoureuse
}

Daniela Dalla Valle

\section{(2) OpenEdition}

\section{Journals}

\section{Edizione digitale}

URL: http://journals.openedition.org/studifrancesi/9175

DOI: $10.4000 /$ studifrancesi.9175

ISSN: 2421-5856

\section{Editore}

Rosenberg \& Sellier

\section{Edizione cartacea}

Data di pubblicazione: 1 juin 2008

Paginazione: 177

ISSN: 0039-2944

\section{Notizia bibliografica digitale}

Daniela Dalla Valle, «Gisèle Mathieu-Castellani, Eros baroque. Anthologie thématique de la poésie

amoureuse», Studi Francesi [Online], 154 (LII | I) | 2008, online dal 30 novembre 2015, consultato il 11 janvier 2021. URL: http://journals.openedition.org/studifrancesi/9175 ; DOI: https://doi.org/10.4000/ studifrancesi.9175

Questo documento è stato generato automaticamente il 11 janvier 2021.

\section{cc) (ㅇ) $\ominus$}

Studi Francesi è distribuita con Licenza Creative Commons Attribuzione - Non commerciale - Non opere derivate 4.0 Internazionale. 


\title{
Gisèle Mathieu-Castellani, Eros baroque. Anthologie thématique de la poésie amoureuse
}

\author{
Daniela Dalla Valle
}

\section{NOTIZIA}

GISÈLE MATHIEU-CASTELLANI, Eros baroque. Anthologie thématique de la poésie amoureuse.

Nouvelle édition, Paris, Champion, 2007, pp. 320.

1 Segnalare qui, nel 2007, la nuova edizione di un'antologia uscita per la prima volta nel 1979 nella collezione 10/18, riprodotta poi da Nizet nel 1986, un'antologia allora molto preziosa, - perché come quella di Jean Rousset, ma con un'impostazione diversa, serviva a restituire alla lettura dei francesi la conoscenza di una serie di poeti cinquesecenteschi definiti 'barocchi' e completamente dimenticati - non compete normalmente alla nostra rassegna. L'antologia di Gisèle Mathieu-Castellani, infatti, riproduce oggi la stessa bella introduzione, gli stessi testi, con poche correzioni.

2 Mi è parso tuttavia utile e importante segnalare questa ripresa di un testo allora utilissimo, in quegli anni della rilettura del barocco francese, perché oggi si sta diffondendo non solo una crisi del barocco - cosa utilissima, soprattutto per chi se ne è servito anche troppo - ma anche una negazione del barocco, un rifiuto dell'esistenza di una letteratura che credevamo di aver rimesso in discussione e che non vorremmo assolutamente dimenticare. 